\title{
Developing students' leadership skills at higher educational institutions for their successful adaptation at the labor market
}

\author{
Maria Mizintseva \\ VINITI RAN \\ 20 Usievicha Street, Moscow \\ Economics Faculty, Peoples' Friendship University of Russia (RUDN University) \\ 6 Miklukho-Maklaja Street, 125 190, Moscow \\ Russian Federation \\ e-mail: mizintseva_mf@pfur.ru
}

\author{
Anna Sardarian \\ Economics Faculty, Peoples' Friendship University of Russia (RUDN University) \\ 6 Miklukho-Maklaja Street, Moscow, 117198 \\ Department of Economics and management, VINITI RAN \\ 20 Usievicha Street, 125 190, Moscow \\ Russian Federation \\ e-mail: sardaryan_ar@pfur.ru
}

\author{
Alena Petrochenko \\ Management Department, Economics Faculty \\ Peoples' Friendship University of Russia (RUDN University) \\ 6 Miklukho-Maklaja Street, Moscow, 117198 \\ Russian Federation \\ e-mail: petrochenko_aa@rudn.university
}

\begin{abstract}
Our paper investigates key tools of developing students' leadership at higher educational institution for their successful adaptation in the labor market. The key problems facing the youth labor market today are: a high rate of real youth unemployment, the problem of neet-youth, discrimination in the labor market on the ground of age, etc. The article substantiates the urgency of studying the phenomenon of leadership, highlighting the most important leadership qualities and searching for ways of their formation and further development in young people. It also gives a brief description of leadership as a social phenomenon, provides basic approaches to leadership, and highlights key qualities of today's leaders. The paper presents summarized results of a survey conducted among modern international higher educational institution students on the necessary qualities of a leader among students of a modern international university, during which there were named the following key qualities (self-confidence, independent character, public-speaking abilities, riskiness, sense of humor) and the least important from students' point of view (tact, adaptability, insight into human nature, and sympathy). It also emphasises the main methods of developing young people's leadership, among which we should mention: creative and project activities, trainings and master classes on leadership, meetings with experts, selfmanagement, special courses in leadership within educational programs, competitions, participation in R\&D, extracurricular activities, leadership schools. We place particular emphasis on the importance of comprehensive approach to the development of leadership qualities of students at modern institutions of higher professional education, covering all tools for developing leadership skills.
\end{abstract}

\section{Introduction}

Nowadays, the mission of educational institutions at all levels (especially institutions of higher professional education) is to train not only highly qualified personnel for the labor market, but also to provide each graduate with the opportunities of professional growth. It is obvious that the professional growth is caused by not only the individual's knowledge and skills in the profession, but also by some set of qualities that allows an individual to be more competitive among the similar highly skilled professionals in the labor market. Among these qualities we can name: assertiveness, willingness to take risks, ability to work in a team environment, sociability and emotional intelligence. Similar qualities characterize a person with strong leadership capability, the development of which becomes today one of the most urgent tasks for institutions of higher professional education. All of the above-mentioned qualities are reasons for studying the development of young people' leadership capabilities, especially university and college students, identifying the basic qualities and skills essential for their further 
development, searching for the best tools and methods of shaping and developing young people's leadership behavior in the educational process at a modern university.

Nowadays, in the scientific literature one can find many works on some aspects of leadership. This subject area has become particularly popular since the mid- $20^{\text {th }}$ century. Thus, the main qualities of the leader and their difference from the administrative manager are widely studied in the works by Bennis (1989), Mann (1959), Stogdill (1974). Moreover, the features and behavior forms of the leader were examined in the works Likert (1967), Lewin (1939), and Mills and Gerth (1952). Among modern researchers of leadership focusing on this phenomenon, a complex of its behavioral aspects, individual characteristics and certain acquired leadership skills, we can single out the following: Blanchard (2011), Drucher (2014) Ilin (2015) Goleman et al. 2002, Vries (2012), von Daan (2013), Parabellum and Belanovsky (2015), Shain (2012), Young (2013), Lazányi et al. (2017), or Bordean and Sonea (2018).

\section{Features of modern youth as a labour force}

It is customary to define "youth" as the group of people between 16 and 24 years of age. However, in some countries (including the Russian Federation) young people are considered to be people of a later age (in the Russian Federation - up to 30 years inclusive). (Decree of the Government of the RF) This socio-demographic group today is rather vulnerable on the labor market (high level of youth unemployment in almost all countries of the world, discrimination in the labor market on the grounds of age (difficulty in finding a job with no experience of work in good positions, low wages of young people compared to other employees and so forth).

One of the most serious problems on the youth labor market is the high level of both official and real unemployment. According to ILO statistics, more than 70 million young people are unemployed, (ILO, 2018) and in some countries the official unemployment rate is up to $50 \%$ (Table 1).

Table 1. World countries with low official youth unemployment rate (2017)

\begin{tabular}{|c|c|c|}
\hline No. & Country & Index, $\%$ \\
\hline 1 & Palestine & 46.9 \\
\hline 2 & Cabo Verde & 41.0 \\
\hline 3 & Greece & 39.5 \\
\hline 4 & Spain & 37.9 \\
\hline 5 & Nigeria & 33.1 \\
\hline 6 & Italy & 32.7 \\
\hline 7 & Georgia & 30.0 \\
\hline 8 & Morocco & 29.3 \\
\hline 9 & Iran & 29.2 \\
\hline 10 & Serbia & 28.9 \\
\hline
\end{tabular}

Source: Own results

In general, the official unemployment rate in the European Union accounts to $16 \%$. The lowest level of this index, according to statistical data, is in Kazakhstan (4\%), Japan (4.1\%), Czech Republic (5\%), Thailand (5.2\%), Hong Kong (5.3\%), Germany (6,6\%). According to the Federal State Statistics (2018) Service of the Russian Federation, there are $23.6 \%$ unemployed young people in Russia. (Federal State Statistics 2018)

Another challenge of the modern generation is the problem of neet (nowhere else working and nowhere else studying category of youth). For the first time this concept began to be used in the late 1990s, (Report by the Social Exclusion Unit 1999) and today it is one of the current issues in studying the problems of youth employment. And although according to Eurostat, this group includes nowhere else working and nowhere else studying young people aged 15 to 24, recently there have been discussions to expand this group to the age of 29 (Eurostat 2011). The index of the youth in recent years has been in Europe from 5\% to 22\%, depending on the countries. The countries with the lowest figures of neet were the Netherlands, Germany, Austria, Denmark (5$7 \%$ ), while Greece, Italy, Spain, Croatia and Bulgaria were the countries with the highest figures (19-22\%). In Russia, this index has totaled about $12 \%$ in recent years. (Varshavskaya 2015)

A particular problem on the youth labor market is discrimination on the grounds of age. Thus, for young people without work experience, even with high qualifications, it is difficult to find good jobs, in the early years they can apply for a job with a relatively low level of salaries and social benefits. In recent years, the labor market has clearly seen a trend to reduce wages, including for young people. For example, in Russia in 2016 the average salary of young specialists without work experience was slightly higher than $\$ 350$. The highest salaries in recent years were paid to young professionals with no experience in the field of finance, law, personnel management, and marketing (Carreer RU 2017). 
At present, in the labor market, a zone of severe competition, for young people it is a challenge to prove themselves, demonstrate their abilities and find a decent job. Obviously, under equal conditions (even possessing high qualifications), the preference is given to the most active young people with a number of specific qualities, including those related to leadership. The article substantiates the urgency of studying the phenomenon of leadership, highlighting the most important leadership characteristics and searching for ways of their formation and further development in young people.

\section{Leadership as a social phenomenon}

The problems of leadership have long occupied psychologists, political scientists, sociologists, administrative staff, social psychologists; nevertheless, there is still no unified theory explaining the nature of leadership, a common set of leadership qualities, as well a dilemma has not been resolved: whether it is possible to become a good leader or leadership is something you have to be born with. Every researcher interprets leadership in their own way attributing different set of characteristics to it.

For example, Virgiles E.V. believes that leadership is a kind of authority exercised by one or more individuals and characterized by its direction from the top downwards. (Vergiles 2001) Leadership as a specific type of management relations, according to Russian researchers Vikhanskiy O. and Naumov A., is based more on the process of social impact, or to be more precise, on the interaction in the organization. This process is immensely complicated and requires a high level of its participants' interdependence. Unlike actual management, leadership presupposes the presence in the organization of followers, not subordinates. (Vikhansky and Naumov 2014)

It should be noted that experts dealing with the aspects of this phenomenon are divided into two categories; some of them consider leadership and administration concepts opposing to each other, while others promote the view that these concepts are close and intersect with each other. Thus, according to Virgiles E.V., the opposition of leadership and administration is methodologically inappropriate, so we can only speak about the various aspects of the same phenomenon, which they traditionally focus on. For example, the term "administratice executive" highlights the formal side of leadership, while "informal leadership' focuses on the subjective side of administration. In practice, any leader tries to be an informal leader. (Vergiles 2001))

Every individual can be characterized as a superior or subordinate. At a certain point in time, when they become adult, young people should realize to what category they belong for the purpose of further successful self-realization. Individuals can successfully realize themselves if correctly chooses their social roles, what they are entitled to receive in social life. (Birman 2015)

For a long time, experts dealing with leadership, tried to identify a set of qualities that would characterize the leader. At the beginning of the previous century, these studies were carried out by Bennis W., Mann R. and Stogdill R. Basically, they attributed to leaders such qualities as the ability to assume their responsibilities, selfconfidence, factual knowledge, determination, accountability, speaking ability, a sense of empathy, energy. For example, Stogdill R. attributed to the most typical features of the leader the following: responsibility, energy, willingness to learn, and spacious mind. Mann R. attributed to leaders: intelligence, adaptability, new receptivity, empathy, extraversion, ability to influence people and lead them.

Table 2. Distinction between a manager and leader

\begin{tabular}{|c|c|}
\hline Executive & Leader \\
\hline Administrator & Innovator \\
\hline Commands, convinces & Inspires, calls to do something \\
\hline Operates on the basis of calculation & Operates on the basis of vision \\
\hline Focuses on the institution & Focus on the staff \\
\hline Supervises & Trusts \\
\hline Professional & Enthusiast \\
\hline Supports movement & Gives impetus to movement \\
\hline Makes decisions & Implements decisions \\
\hline Is respected & Popular \\
\hline
\end{tabular}

Source: Vikhansky and Naumov (2014)

However, the approach of combining certain qualities in a unified system was faced with criticism from the adherents of the behavioral approach (Likert R., Levin K., etc.) who believed that the leader is characterized with a set of certain behavioral specific features and skills, as well some "auxiliary" factors of organizational 
environment (corporate culture, norms and traditions, entrenched in the organization, etc.) The beginning of this century saw the emergence of some other, complex, theories of the personality of the leader, where the leader was seen as the inspirer, the generator of ideas and the motivator of the subordinates under his/her leadership (Goleman et al. 2002). According to Vikhansky and Naumov (2014), leadership is not management, since management is based on encouraging subordinates to do "things correctly", while leadership is to "do the right things" (Birman 2015) (Table 2 above).

It seems interesting to the authors to highlight the leadership qualities that modern students most often see in this notion. Thus, on the basis of a number of surveys conducted at the Economics Faculty, RUDN University, in 2015-2016, when studying the topic "Leadership and Administration" within the framework of the course "Organizational Behavior" more that 200 students identified that the main qualities of the leader are: selfconfidence $(86.4 \%)$, independence of character $(76.7 \%)$, public-speaking abilities $(62.1 \%)$ willingness to risk $(51.9 \%)$, sense of humor (49.1\%) (Figure 1). To a lesser extent, diplomacy (6.8\%), adaptability (8.3\%), ability to understand people (10.7\%), empathy (11.1\%) were classified as the leadership qualities (Figure 2).
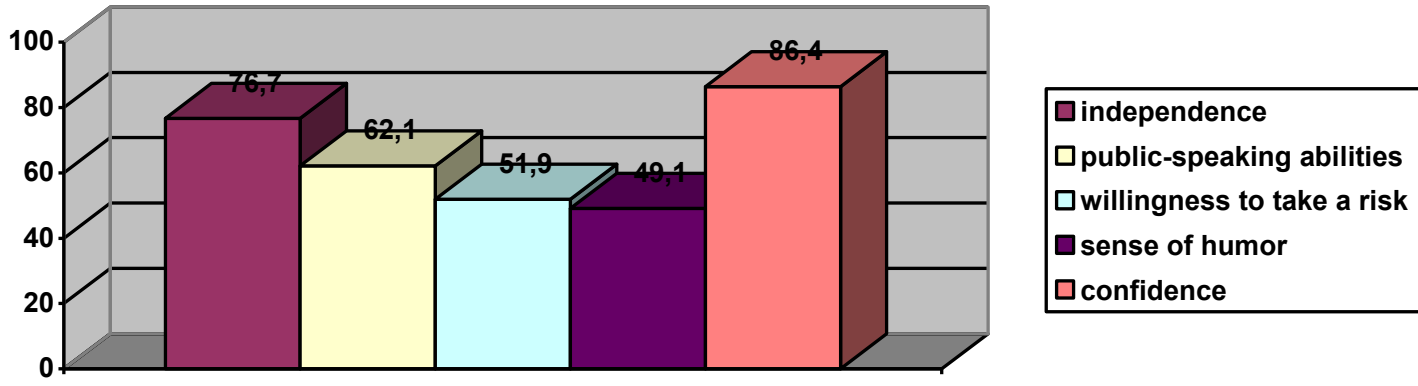

Fig. 1. The key qualities of a modern leader (according to students) Source: Own results

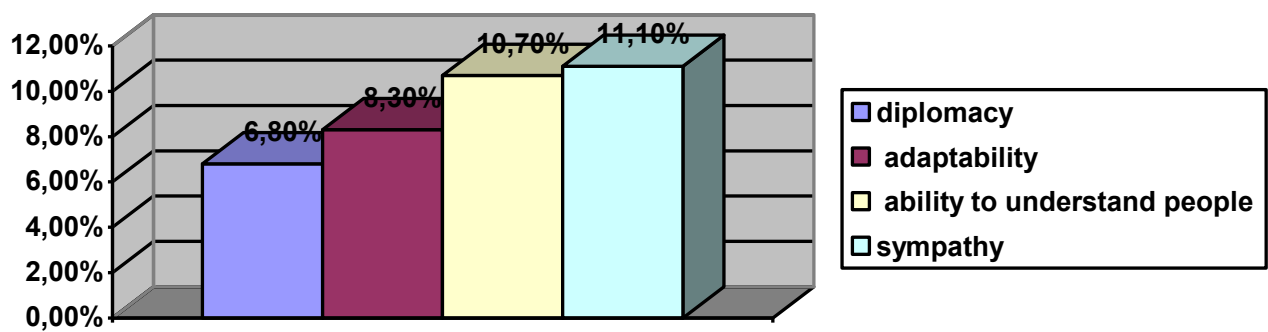

Fig. 2. The less important qualities of a modern leader (according to students)

Source: Own results

Leadership qualities are necessary for young people entering the labor market after universities, as the labor market is an environment that witnesses serious problems nowadays (high rate of real unemployment, especially among young people, severe competition, high requirements for young professionals). In addition, the projected transformation of the labor market in the coming decades also dictates new rules and makes leadership approach for young people imperative. Leader's skills are necessary in starting a business, getting a good position in a company with no experience of working in a team even if the company operates remotely.

\section{Methods of developing young people' leadership capabilities}

Researchers and practical managers argue if it is possible to become a leader or it is something you have to be born with. For example, American management states that practically any person can be developed into a leader. Japan approach to leadership is different; they say that you should be born a leader. The authors of this paper think that more grounded position is that leadership can be partly inborn, but some leadership skills are also possible to develop, and in the current highly competitive situation on the labor market and high requirements for specialists it is absolutely imperative.

According to experts, the number of students with a highly developed leadership capabilities is no more than $10 \%$, and such qualities as responsibility, commitment, efficiency, initiative, are distinctive features of no more 
than half of graduates (Kozybakova 2010). We have to state the fact that educational institutions pay more attention to the development of knowledge, competences and skills in specific disciplines than professional and personal growth of students. Nevertheless, the development of leadership capabilities is the most important process on the path of personal development; it allows approaching the issue of professional growth comprehensively (Naumov and Baranov 2015).

The mode of behavior, including leadership, is largely laid down during childhood and school time, thus, the first "trainers" of leadership qualities are the family and the school. However, in this paper more emphasis is placed on the formation of leadership qualities in a more mature age, among 17-year-old young people, who are, as a rule, universities or specialized colleges students.

First of all, in the process of training young people, it is important to combine the theoretical presentation of the material (lectures) with the practical one with clear feedback (seminars, master classes, trainings, etc.) Higher educational institutions often effectively train public speaking skills, important for the future leader. Particular important in the identification and training of leadership skills (responsibility, ability to take risks, ability to make decisions, flexibility, teamwork skills) is project activity - work on a specific project in a small group.

Today, business games that reveal the leadership capabilities of the participants have become popular. Although they are still not so popular in Russian universities, this practice is gradually being introduced into the coursework of universities and colleges. Although, it is worth noting that the first business game was developed in the USSR in 1932 by Birshtein M., however in the Soviet Union for a long time such games were banned. In the 1960s, Abt C., Greenblatt C., Gray F. and others worked on the development of business games in the USA. Business game as a method of imitating decision-making in various manufacturing situations in multitasking and uncertainty is aimed at developing practical decision-making skills in the group, to stimulate the obtaining of leadership qualities, the ability to respond quickly to changing challenges.

Some students demonstrate their capabilities as a leader in their R\&D activity. In this regard, it is necessary to emphasize the role of the research manager, setting clear tasks for the participants, developing teamwork skills, revealing the personal potential of each performer, inspiring and stimulating further R\&D efforts.

Particular importance is attached to specialized courses within the university curricular for students studying a number of specialities (in particular Management, PR, Journalism, Banking, Foreign Affairs etc. In this curricular it is worth noticing such courses as Leadership, Personal Efficiency, and Talent Management etc. In the framework of such courses, it is advisable to focus on the disclosure and development of leadership capacities, the formation of the necessary qualities in the young people that are relevant to the labor market in the presence of high qualifications - responsibility, communication skills, stress resistance, riskiness, ability to manage,

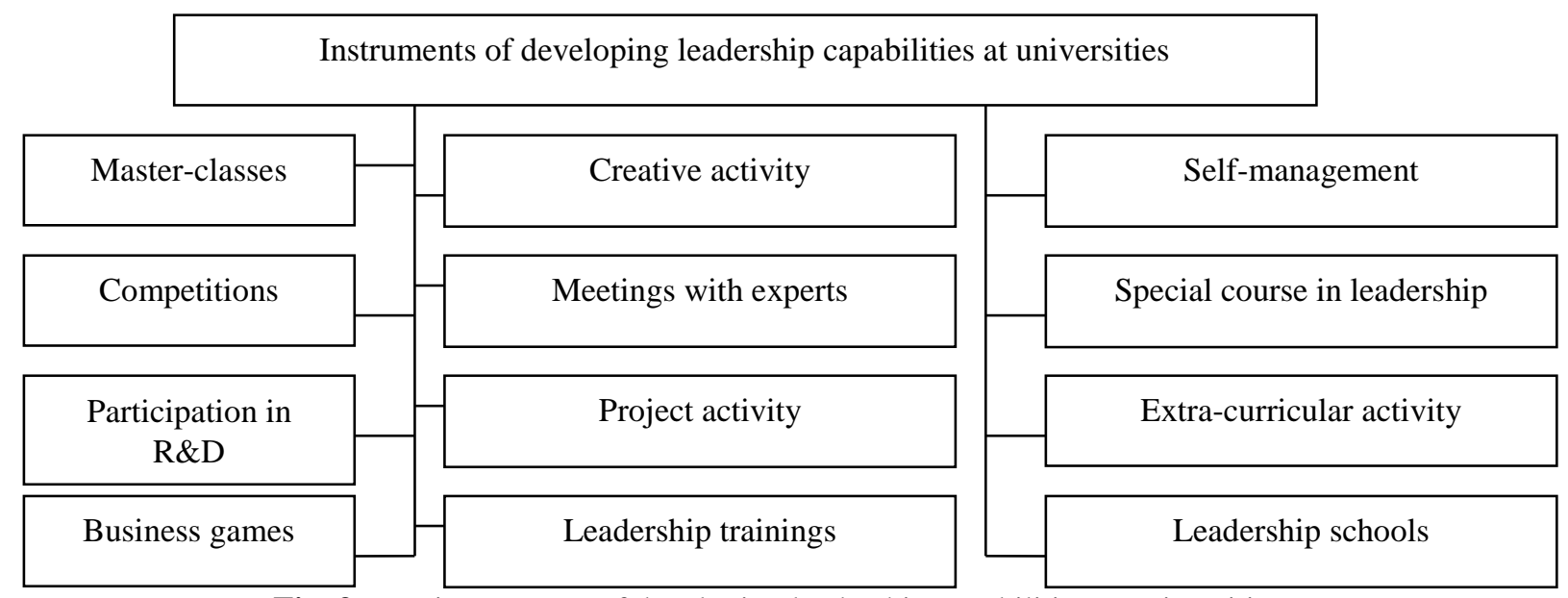

Fig. 3. Key instruments of developing leadership capabilities at universities

Source: Own results

Extra-curricular activities of students (participating in amateur competitions and interest groups, volunteering, organizing of academic department, faculty and university events, etc.) also contribute to the development of above-mentioned skills. Modern colleges and universities put into practice students' construction brigades, association of fellow-countrymen, students' TV, interest groups, including sports clubs, amateur talent groups etc. Students' leadership skills are also developed by self-management - a way of organizing students' body by its members for a short or longer time. This method is popular, for example, at schools (days of self-management), and sometimes can be implemented at colleges and universities. 
Master classes and trainings on leadership skills at institutions of higher professional education carries out by invited successful business representatives and well-known trainers are also effective methods to reveal and develop leadership qualities in young people.

It is especially worth highlighting the introduction of leadership schools in the practice of modern higher education institutions, in the framework of which events can be organized to develop leadership skills and competences: confidence, critical thinking, emotional resilience, intellectual abilities and creativity, teamwork skills, perseverance, self-criticism, communication skills, etc. Leadership schools can conduct master classes and leadership trainings, contests, creative works, project activities, discussions, supervision of junior students, meetings with experts and interesting people.

Thence, it should be emphasized that the approach to developing leadership qualities in young people students of modern institutions of higher professional education should be comprehensive and cover all tools for developing leadership skills (see Figure 3).

\section{Conclusions}

This paper studied the key tools for developing leadership skills in students of institutions of higher professional education. The paper managed to explore the main problems on the youth labor market, identified approaches to leadership and revealed the role of leadership capabilities and skills among graduates from higher education institutions in process of their adaptation to the labor market as well the basic qualities of the leader, including in the students' opinion, gave a brief description of the tools for developing leadership qualities in students of institutions of higher professional education.

The authors hope that further research in this area will become more extensive in the very near future. The results and conclusions obtained in the course of work on this paper can help the administration of modern universities add to the main tasks of higher education activities the component of teaching and developing leadership skills in students. As well, the materials of this paper can be used in further scientific research and practical developments on the development of leadership skills in students of modern universities.

\section{Acknowledgments}

This paper was financially supported by the Ministry of Education and Science of the Russian Federation on the program to improve the competitiveness of Peoples' Friendship University of Russia (RUDN University) among the world's leading research and education centers in the 2016-2020.

\section{References}

Bennis W, On Becoming a Leader, $1^{\text {st }}$ edn. (Addison Wesley: New York, 1989), 202 p.

Birman L, Obshiy menegment, $2^{\text {nd }}$ edn. (Delo: Moscow ANE, 2015), 398 p.

Blanchard K, Leading at a higher level, updated $2^{\text {nd }}$ edn. (Blanchard Management Corporation: New Jersey, 2010), $351 \mathrm{p}$.

Bordean ON, Sonea A (2018) Student satisfaction and perceived skills: any link to employability? Entrepreneurship and Sustainability Issues 6(1): 356-370. doi: 10.9770/jesi.2018.6.1(22)

Bridging the gap: New opportunities for 16-18 year olds not in education, employment or training. Report by the Social Exclusion Unit (1999). http://dera.ioe.ac.uk/15119/2/bridging-the-gap.pdf Accessed 05 Aug 2018

Carreer RU (2017) Average salary of young specialists. https://career.ru/article/18781 Accessed 30 Jul 2018

Decree of the Government of the Russian Federation, December 18, 2006, N 1760-r "About the approval of the strategy of the state youth policy in the Russian Federation" (as amended on 18.12.2009 No. 997-r) http://en.gosnadzor.ru/framework/nuclear/RF\%20Government\%20Decree\%20No.794.doc Accessed 06 Aug 2018

Drucker P, Effektivnyi rukovoditel, 3d edn, per. s angl O. Chernyavskoj (Mann, Ivanov and Ferber: Moscow, 2014), 232 p.

Eurostat (2011). Youth neither in employment nor education and training (NEET) (2011). Presentation of data for the 27 Member States. European Commission, EMCO Contribution . http://ec.europa.eu/social/BlobServlet?docId=6602\&langId=en Accessed 30 Aug 2018 
Federal State Statistics (2018) The site of the Federal State Statistics Service of the Russian Federation. http://www.gks.ru/wps/wcm/connect/rosstat_main/rosstat/ru/statistics/wages/labour_force/ Accessed 30 Aug 2018

Gerth H, Mills C, A sociological note on leadership. In: Problems in Social Psychology (University of Illinois Press: Urbana, 1952), pp. 145-155

Goleman D, Boyatzis R, McKee A, Primal Leadership. Learning to Lead With Emotional Intellect (Harvard Business School Press: Boston, 2002), 301 p.

Ilin V, Psihologija liderstva, $1^{\text {st }}$ edn, (Urait: Moscow, 2015), 311 p.

Kets de Vries M, Mistika liderstva: razvitije emocionalnogo intellekta,transl.M. Shalunova, $1^{\text {st }}$ edn, (Alpina Publisher: Moscow, 2004), 311 p.

Kozybakova G, Development of leadership qualities in university students. Published summary of a dissertation for a Candidate Degree in Candidate of pedagogic sciences (Republic of Kazakhstan, 2010).

Lazányi K, Čepel M, Bilan S (2017) Comparison of Trust and Social Relations among Students in Russian and Hungarian Higher Education. Economics and Sociology 10(4):162-174. doi:10.14254/2071-789X.2017/10-4/13

Lewin K, Lippitt R, White R (1939) Patterns of Aggressive Behavior in Experimentally - Created Social Climates. Journal of Social Psychology 10 (2) :271-301. doi: 10.1080/00224545.1939.9713366

Likert R, The Human Organization (McGraw: Hill, 1967), 258 p.

Mann R (1959) A review of the Relationships between Personality and Performance in Small Groups. Psychologocal Bulletin 56(4):241-270. doi: 10.1037/h0044587

Naumov T, Baranov A, Tarakanov Y (2015) Development of leadership qualities in university students. https://naukovedenie.ru/PDF/108PVN415.pdf Accessed 5 Aug 2016

Parabellum A, Belanovsky L, Vlast, liderstvo, charizma (AST: Moscow, 2016), 240 p.

Schein E. H, Organizacionnaya kultura i liderstvo tr. from English, ed. by V.A. Spivak (Piter: St. Petersburg, 2002), $336 \mathrm{p}$.

Stogftll R, Handbook of Leadership (The Free Press: New York, 1974), 576 p.

The International Labour Organization. Official site. http://www.ilo.org Accessed 30 Aug 2018

Van Knippenberg B, Leadership and Power. Identity Processes in Groups and Organizations, ed. by Hogg, $1^{\text {st }}$ edn. (Sage Publications: London, 2003), 257 p.

Varshavskaya E (2015) Young people excluded from employment and education in the EU and Russia. Voprosy statistiky 4: 40-47.

Vergiles E, Theory of Leadership (Moscow State University of Economics, Statistics and Informatics Moscow, 2001), $42 \mathrm{p}$

Vikhansky O, Naumov A, Menegment, 5th edn. (Magistr: INFRA-M, 2014), 428 p.

Young R, Individual's character strengths. How to influence people and events, tr. from english (Pretext: Moscow, 2013), $220 \mathrm{p}$.

Youth unemployment (2017) http://ru.tradingeconomics.com/forecast/youth-unemployment-rate Accessed 30 Aug 2018 